\title{
Is it possible to preserve the blood supply of erectile organs by anastomosis using the hypogastric artery in kidney transplantation?
}

This article was published in the following Dove Press journal: International Journal of Nephrology and Renovascular Disease 10 July 2017

Number of times this article has been viewed

\section{Afshar Zomorrodi' \\ Farzad Kakaei ${ }^{2}$ \\ Sahar Zomorrodi ${ }^{3}$ \\ Amin Bagheri'}

'Department of Urology and Kidney Transplantation, Emam Reza Hospital, Tabriz University of Medical Sciences, Tabriz, Iran; ${ }^{2}$ Department of Surgery, Emam Reza Hospital, Tabriz University of Medical Sciences, Tabriz, Iran; ${ }^{3}$ Tabriz University of Medical Sciences, Tabriz, Iran
Correspondence: Farzad Kakaei Department of Surgery, Emam Reza Hospital, Daneshgah Street, Tabriz 5165687386, Iran

Tel +98 4l 35553407

$\mathrm{Fax}+984133347054$

Email fkakaei@yahoo.com
Introduction: Three modalities for treating chronic kidney failure are peritoneal dialysis, hemodialysis, and kidney transplantation. Among them kidney transplantation is cost-efficient and leads to a somewhat normal quality of life. In this approach, most often the external iliac artery is selected for anastomosis, but this could be disastrous if anastomosis leads to a complication. The traditional end-to-end approach for anastomosis of the kidney artery to the internal iliac artery leads to pelvic organ ischemia. However, if the end-to-end anastomosis is replaced by an end-to-side approach, it is safer. This report discusses some cases of end-to-side anastomosis using the internal iliac artery.

Method: In ten cases of chronic kidney failure, we anastomosed the kidney artery to the internal iliac artery with an end-to-side approach.

Results: After vessels were unclamped, all patients had diuresis. Their creatinine was in normal range and was blood flow in the internal iliac artery, based on color Doppler ultrasound.

Conclusion: End-to-side anastomosis can be done in some chronic kidney failure patients if their internal iliac arteries are large enough. This approach is safer than anastomosis using the external iliac artery.

Keywords: kidney transplant, internal iliac artery, anastomosis

\section{Introduction}

The most effective treatment for chronic kidney failure is kidney transplantation in which the external iliac artery is used to preserve pelvic organs' circulation. Using the internal iliac artery for end-to-end anastomosis is a traditional approach for kidney transplantation (Figure 1). Even in repeated kidney transplantation the end-to-end is preferred to the end-to-side approach.

Kidney transplantation is the preferred choice of treatment for chronic kidney failure because it offers the patient a "near normal" lifestyle. Vascular anastomosis is still done according to Alex Carrel's technique for kidney transplantation and Kuss' technique for pelvic vessels. ${ }^{1}$ With this method the hypogastric artery or external iliac artery is selected for vessel anastomosis.

The traditional approach used a pelvic vessel such as the internal iliac artery, ${ }^{2}$ but later the external iliac artery was used for preserving pelvic organs' circulation, especially in the penis. ${ }^{3}$ End-to-end anastomosis using the hypogastric artery has been claimed to reduce the penis' blood circulation, ${ }^{3}$ as it is suggested that $50 \%$ of chronic kidney failure patients suffer from erectile dysfunction. Some studies suggest that endto-end anastomosis is an etiology of post-kidney transplantation erectile dysfunction. ${ }^{4}$ 
A

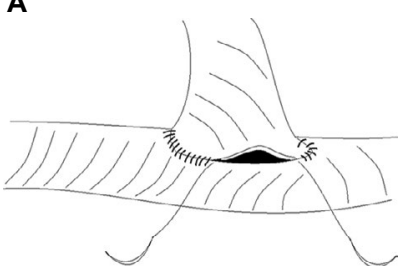

B

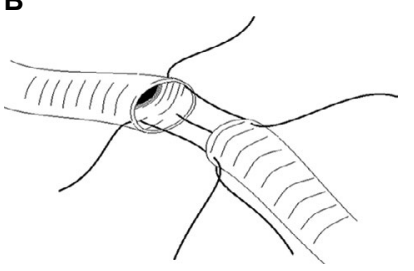

Figure I (A) End-to-side anastomosis, (B) end-to-end anastomosis.

Claudication has also been reported after end-to-end internal iliac artery anastomosis. ${ }^{5}$

To our knowledge, there has only been one study on endto-side anastomosis of the internal iliac artery in a general hospital in Leicester, UK. ${ }^{6}$ Ours is the second to discuss some cases of end-to-side anastomosis using the internal iliac artery in a hospital in Tabirz city, Iran.

\section{Cases}

This study was done on ten kidney transplant patients (Table 1). The end-to-side internal iliac artery anastomosis approach was used in all patients.

One of the cases was a 45-year-old male with chronic kidney failure because of hypertension. Kidney transplantation was carried out with allograft kidney procured from an unrelated live donor. It was the donor's left kidney. To prepare the recipient's hypogastric artery, we performed end-to-side kidney artery anastomosis. After 2 months' follow-up his creatinine level was normal $=0.3 \mathrm{mg} / \mathrm{dL}$ (Figure 2).

Another case was a 25-year-old male with chronic kidney failure due to glomerulopathy. We performed end-to-side anastomosis using the hypogastric (internal iliac) artery with good results (Figure 3 ). His creatinine level was $1.5 \mathrm{mg} / \mathrm{dL}$ after 2 months. He was treated with tacrolimus, CellCept ${ }^{\circledR}$ (mycophenolate mofetil), and prednisolone.

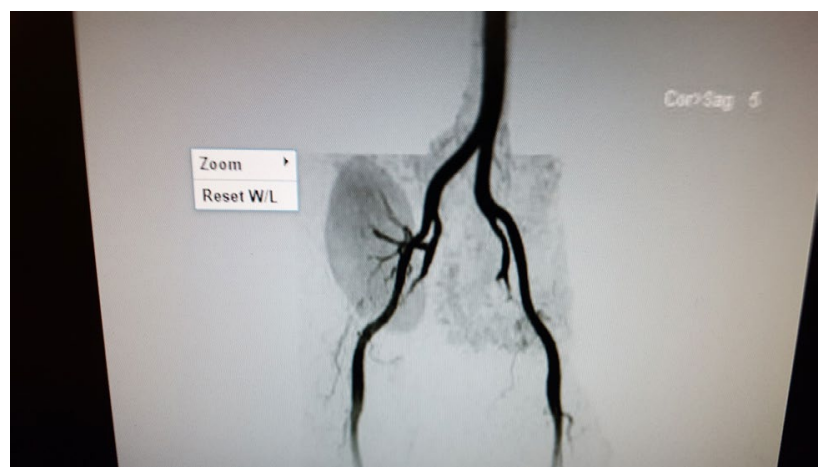

Figure 2 Magnetic resonance angiogram of allograft kidney with end-to-side anastomosis using the internal iliac artery, and distal blood flow beyond anastomosis.

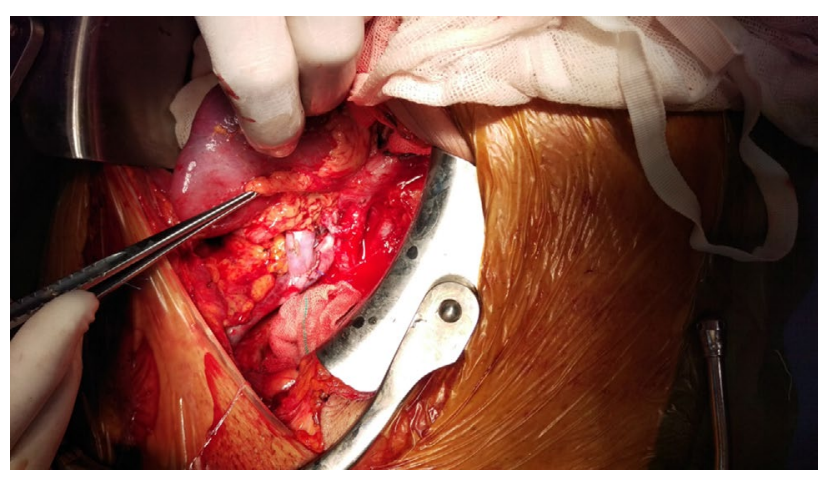

Figure 3 End-to-side anastomosis using the internal iliac artery.

In our hospital more than ten kidney transplantations have been performed successfully by end-to-side anastomosis using the internal iliac artery. All of the patients were treated with tacrolimus, mycophenolate mofetil, and prednisolone and their creatinine levels were $\leq 1.5 \mathrm{mg} / \mathrm{dL}$.

\section{Discussion}

The internal iliac artery separates from the common iliac artery. It has nine branches including: sacral, gluteal inferior, gluteal superior, lumbar, umbilical, obturator artery, superior

Table I The patient's age, sex, race, outcomes, and complications

\begin{tabular}{|c|c|c|c|c|c|c|}
\hline Case & $\begin{array}{l}\text { Age } \\
\text { (years) }\end{array}$ & Sex & Race & $\begin{array}{l}\text { Serum creatinine } \\
2 \text { months after } \\
\text { transplantation, } \mathrm{mg} / \mathrm{dL}\end{array}$ & $\begin{array}{l}\text { Glomerular } \\
\text { filtration } \\
\text { rate, } \mathrm{mL} / \mathrm{min}\end{array}$ & Complications \\
\hline I & 28 & Male & Caucasian & 1.8 & 58.7 & none \\
\hline 2 & 25 & Male & Caucasian & 1.5 & 83 & none \\
\hline 3 & 36 & Female & Caucasian & 1.6 & 56.2 & none \\
\hline 4 & 34 & Male & Caucasian & 1.5 & 67.7 & none \\
\hline 5 & 43 & Female & Caucasian & 1.3 & 67.3 & none \\
\hline 6 & 39 & Male & Caucasian & 1.8 & 45.97 & none \\
\hline 7 & 50 & Male & Caucasian & 2.1 & 44 & none \\
\hline 8 & 47 & Male & Caucasian & 1.9 & 56.4 & none \\
\hline 9 & 29 & Male & Caucasian & 1.5 & 86.3 & none \\
\hline 10 & 42 & Male & Caucasian & 1.6 & 53.5 & none \\
\hline
\end{tabular}


Table 2 Complications and advantages of internal and external iliac artery anastomosis

\begin{tabular}{|c|c|c|c|}
\hline Arteries & Anastomosis & Complications & Advantages \\
\hline \multirow[t]{2}{*}{$\begin{array}{l}\text { External } \\
\text { iliac artery }\end{array}$} & End-to-side & $\begin{array}{l}\text { Possible lower limb } \\
\text { amputation in case } \\
\text { of complications in } \\
\text { the anastomosis site }\end{array}$ & $\begin{array}{l}\text { An easy way } \\
\text { to perform } \\
\text { anastomosis }\end{array}$ \\
\hline & End-to-end & & \\
\hline \multirow[t]{2}{*}{$\begin{array}{l}\text { Internal } \\
\text { iliac artery }\end{array}$} & End-to-side & $\begin{array}{l}\text { Needs release of } \\
\text { internal iliac artery }\end{array}$ & $\begin{array}{l}\text { Preserved arterial } \\
\text { blood supply to } \\
\text { pelvic organs }\end{array}$ \\
\hline & End-to-end & $\begin{array}{l}\text { Claudication, } \\
\text { impotence }\end{array}$ & $\begin{array}{l}\text { Easier access } \\
\text { to perform } \\
\text { anastomosis }\end{array}$ \\
\hline
\end{tabular}

vesical, inferior vesical, and pudendal. In end-to-end anastomosis using the kidney artery we omit nine internal iliac artery branches. This can have consequences for a kidney transplant recipient. For example, omitting the pudendal branch reduces perfusion of penile arteries ${ }^{5}$ and causes erectile dysfunction; or omission of the gluteal branch causes claudication $^{5}$ (Table 2).

Considering that erectile dysfunction is more common in kidney transplant patients, the end-to-side instead of endto-end anastomosis approach can be useful in a patient with high risk of erectile dysfunction and claudication, especially in young people, if the internal iliac artery is large enough in diameter for anastomosis. Also, if there is arterial plaque, it is possible to perform an endarterectomy and then end-to-side anastomosis to preserve pelvic organs' perfusion, especially erectile organs' blood flow.

\section{Conclusion}

Chronic kidney failure can be associated with a pelvic organ dysfunction if the hypogastric artery is used for anastomosis.
End-to-side anastomosis can be considered instead, to preserve pelvic organs' blood flow, especially the erectile organs, in young people.

\section{Ethics statement}

This study was approved by the ethics committee of Tabriz University of Medical Sciences (code number: IR.TBZMED. REC.1394.769). The two patients whose cases are reported signed an informed consent for publication of their case details.

\section{Acknowledgment}

The authors thank Seyed Muhammed Hussein Mousavinasab for his sincere cooperation in editing this text.

\section{Disclosure}

The authors report no conflicts of interest in this work.

\section{References}

1. Carrel A. Suture of Blood-Vessels and transplantation of Organs. In Nobel Lectures, Physiology or Medicine 1901-1921. Singapore: World Scientific Publishing Company; 1999:442-464.

2. Mosley JG, Castro JE. Arterial anastomoses in renal transplantation. Br J Surg. 1978;65(1):60-63.

3. Abdel-Hamid IA, Eraky I, Fouda MA, Mansour OE. Role of penile vascular insufficiency in erectile dysfunction in renal transplant recipients. Int J Impot Res. 2002;14(1):32-37.

4. El-Bahnasawy MS, El-Assmy A, Dawood A, et al. Effect of the use of internal iliac artery for renal transplantation on penile vascularity and erectile function: a prospective study. $J$ Urol. 2004;172(6 Pt 1) 2335-2339.

5. Rayt HS, Bown MJ, Lambert KV, et al. Buttock claudication and erectile dysfunction after internal iliac artery embolization in patients prior to endovascular aortic aneurysm repair. Cardiovasc Intervent Radiol. 2008;31(4):728-734.

6. Mohamed IH, Bagul A, Doughman T, Nicholson ML. Use of internal iliac artery as a side-to-end anastomosis in renal transplantation. Ann $R$ Coll Surg Engl. 2012;94(1):e36-e37.

\section{Publish your work in this journal}

The International Journal of Nephrology and Renovascular Disease is an international, peer-reviewed open access journal focusing on the pathophysiology of the kidney and vascular supply. Epidemiology, screening, diagnosis, and treatment interventions are covered as well as basic science, biochemical and immunological studies. The manuscript management system is completely online and includes a very quick and fair peer-review system, which is all easy to use. Visit http://www. dovepress.com/testimonials.php to read real quotes from published authors. 